Article

\title{
Sulfur Isotope Fractionation as an Indicator of Biogeochemical Processes in an AMD Passive Bioremediation System
}

\author{
Liliana Lefticariu ${ }^{1,2, *}$, Paul T. Behum ${ }^{2,3}$, Kelly S. Bender ${ }^{4}$ and Mihai Lefticariu ${ }^{5}$ \\ 1 Department of Geology, Southern Illinois University, Carbondale, IL 62901, USA \\ 2 Environmental Resources and Policy Program, Southern Illinois University, Carbondale, IL 62901, USA; \\ pbehum@osmre.gov \\ 3 Office of Surface Mining Reclamation and Enforcement, Alton, IL 62002, USA \\ 4 Department of Microbiology, Southern Illinois University, Carbondale, IL 62901, USA; \\ bender@micro.siu.edu \\ 5 Mass Spectrometry Facility, Southern Illinois University, Carbondale, IL 62901, USA; \\ mihailefticariu@siu.edu \\ * Correspondence: lefticar@siu.edu; Tel.: +1-618-453-7373
}

Academic Editor: Javier Sánchez-España

Received: 2 February 2017; Accepted: 14 March 2017; Published: date

\begin{abstract}
Sulfate, the main dissolved contaminant in acid mine drainage (AMD), is ubiquitous in watersheds affected by coal and metal mining operations worldwide. Engineered passive bioremediation systems (PBS) are low-cost technologies that remediate sulfate contamination by promoting (1) precipitation of sulfate-bearing compounds, such as schwertmannite and gypsum; and (2) microbially-mediated sulfate reduction (BSR) to sulfide with subsequent precipitation of sulfide minerals. In this study, chemical and sulfur isotopic data are used to infer multiple pathways for sulfate sequestration in the Tab-Simco PBS. By simultaneously monitoring sulfate concentrations and ${ }^{34}{ }^{4}$ so4 values at four sampling points across the PBS, we (1) identified that the organic layer within the bioreactor was the primary site of BSR processes contributing to sulfate sequestration; (2) observed seasonal variations of BSR processes; (3) estimated that initially the BSR processes contributed up to $30 \%$ to sulfate sequestration in the Tab-Simco bioreactor; and (4) determined that BSR contribution to sulfate sequestration continuously declined over the PBS operational lifetime. Together, our results highlight the utility of combining geochemical and microbial fingerprinting techniques to decipher complementary processes involved in sulfur cycling in a PBS as well as the value of adding the sulfur isotope approach as an essential tool to help understand, predict, prevent and mitigate sulfate contamination in AMD-impacted systems.
\end{abstract}

Keywords: acid mine drainage; sulfur isotopes; nanoparticles; coal waste; bioremediation

\section{Introduction}

Sulfate $\left(\mathrm{SO}_{4}{ }^{2-}\right)$ is a major contaminant in many watersheds impacted by coal and metal mining activities and is difficult to remediate [1-6]. The increased $\mathrm{SO}_{4}{ }^{2-}$ presence in ecosystems affected by mining has negative environmental and human health effects [7] since $\mathrm{SO}_{4^{2-}}$ can (1) promote secondary water quality impacts related to sulfur (S) redox processes and biological hydrogen sulfide $\left(\mathrm{H}_{2} \mathrm{~S}\right)$ production; (2) stimulate methylation of mercury to methylmercury, the most toxic and bioaccumulative form of mercury; (3) enhance biodegradation of organic matter in soils; and (4) promote release of nutrients and potentially toxic compounds from sediments during biologically-mediated sulfate reduction processes [8-11]. Consequently, decreasing $\mathrm{SO}_{4^{2-}}$ discharge from mine drainages associated with coal and metal mining operations is a priority worldwide [1-4].

Recently, considerable interest has focused on designing remediation technologies of acid mine drainages (AMD), which often contain excessively high concentrations of $\mathrm{SO}_{4}{ }^{2-}$ [12-14]. Engineered 
passive bioremediation systems (PBS) have been proposed as a low-cost, environmentally sustainable option for remediating AMD at metal and coal mining operations [5,12-14]. Preventing the direct mobilization of contaminants from the mine waste is the preferred approach in AMD mitigation; however, in many instances, such as in the case of many abandoned coal mines, there are large uncertainties in the locations of old mine workings and thus underground flooding and sealing is not a viable option [5]. In the Illinois Basin, several engineering designs for PBS have been developed in the recent years. Such systems have used low-cost, locally available materials and consist of gravity-flow systems such as wetlands, oxidation ponds, low-pH iron oxidation cells/open limestone channels, and anaerobic sulfate reducing bioreactors $[5,15,16]$.

In a PBS, $\mathrm{SO}_{4}{ }^{2-}$ immobilization can be achieved through precipitation of neoformed nano- and micro-scale particles (nNP) (e.g., goethite and schwertmannite) and/or adsorption on nNP [6]. Additional $\mathrm{SO}_{4}{ }^{2-}$ sequestration can occur through biologically mediated $\mathrm{SO}_{4}{ }^{2-}$ reduction (BSR) to $\mathrm{H}_{2} \mathrm{~S}$ [5,16-18]. BSR activity $\left(2 \mathrm{CH}_{2} \mathrm{O}+\mathrm{SO}_{4}{ }^{2-} \rightarrow 2 \mathrm{HCO}_{3}{ }^{-}+\mathrm{H}_{2} \mathrm{~S}\right)$ is desirable for mitigating AMD because it removes $\mathrm{SO}_{4}{ }^{2-}$, raises the $\mathrm{pH}$ through bicarbonate alkalinity $\left(\mathrm{HCO}_{3}{ }^{-}\right)$production and yields $\mathrm{H}_{2} \mathrm{~S}$ for precipitating sparingly soluble metal sulfides [17]. Due to their stability, sulfide minerals are seen as the preferred long-term remediation approach for $\mathrm{SO}_{4}{ }^{2-}$ immobilization [5].

One of the most common practices of evaluating PBS remediation efficiency is monitoring the temporal trends of $\mathrm{SO}_{4}{ }^{2-}$ and metal concentrations in the effluent discharge [5]. However, this approach cannot identify the degree of $\mathrm{SO}_{4^{2-}}$ removal by several competing processes that each can lead to a decrease in $\mathrm{SO}_{4}{ }^{2-}$ concentration in the treated AMD effluent, including dilution due to mixing with low-SO $4^{2-}$ waters, precipitation of $\mathrm{SO}_{4}{ }^{2-}$-bearing $\mathrm{nNP}$, and microbially-mediated $\mathrm{SO}_{4}{ }^{2-}$ reduction [15,16]. Certainly, a better understanding of the BSR processes and the nature and distribution of biotic and abiotic pathways of $S$ cycling and sequestration in a PBS could have major benefits on designing more effective bioremediation systems.

This contribution presents geochemical and S isotope data of S-bearing phases in a field-scale PBS treating coal mine AMD. We have employed stable $S$ isotope analyses because this approach is commonly used to discriminate between biologically-mediated sulfate reduction [19-23] and abiological $\mathrm{SO}_{4}{ }^{2-}$ immobilization in $\mathrm{SO}_{4}{ }^{2-}$ bearing $\mathrm{nNP}$ in natural and engineered systems $[24,25]$ as BSR produces some of the largest sulfur isotope fractionations observed in nature [20]. Our previous field experiments showed that $S$ isotopic patterns could provide constraints on the occurrence of BSR in field experiments simulating a PBS [18]. In this study, we illustrate that $S$ isotopes, together with additional supporting microbial and geochemical data, can fingerprint BSR and provide insights into the $\mathrm{S}$ cycling within a field-scale PBS. Importantly, sulfur isotope patterns can become an essential tool to help understand, predict, prevent and mitigate $\mathrm{SO}_{4}{ }^{2-}$ contamination in AMD-impacted systems. However, for a quantitative assessment of BSR, additional experimental work is necessary to further resolve the relationships between isotopic fractionation factors between $\mathrm{SO}_{4}{ }^{2-}$ and microbially-produced $\mathrm{H}_{2} \mathrm{~S}$ and relevant environmental parameters in highly metalliferous AMD-impacted environments.

\section{Background}

\subsection{Description of the Tab-Simco Site}

Tab-Simco is an abandoned mine land site located $\sim 6 \mathrm{~km}$ SE of Carbondale, Illinois, USA [5]. The Tab-Simco coal mine was abandoned in the early 1970s prior to national coal mining environmental regulation and is one of the most highly AMD contaminated sites in the U.S. mid-continent region [26]. The site is located on a 12-hectare highly-dissected plateau with underlying underground mine workings into two Pennsylvanian-age coal seams, the Murphysboro and Mt. Rorah Members of the Spoon Formation [27]. Weathering of coal in the underground workings resulted in the formation of AMD mine pools. Subsequent contour-type surface mining removed the outcrop barrier that surrounded these workings and allowed seepage of the AMD though the mine waste (overburden rock and soil debris). Before the State of Illinois conducted land reclamation in 2007, the AMD had a pH in the 2.0-3.0 range and discharged through a series of seeps 
into a "kill zone", a floodplain coated with Fe-rich precipitates, before exiting into a local creek. Reclamation efforts in the area included sealing the mine opening, backfilling of impoundments, and construction of a bioremediation system that included limestone channels to re-direct run off, a passive sulfate-reducing bioreactor, and a wetland/settling pond (Figure 1).



Figure 1. Plan view of the Tab-Simco site with sample locations indicated: the Main Seep (MS), Bioreactor Inlet (Bio In), Bioreactor Outlet (Bio Out), and the System Outlet (System Out).

The sulfate-reducing bioreactor was initially built in 2007 with $\sim 5887 \mathrm{~m}^{3}$ of limestone-amended organic substrate (53\% wood chips, $27 \%$ straw, $11 \%$ seasoned municipal yard waste) and $9 \%$ agricultural ground limestone by volume [28]. In 2013, after six years of operation, due to decreasing contaminate removal rates, the bioreactor was rehabilitated by replacement of the organic substrate with higher amount of limestone. Two monitoring wells were also completed: B-1 into the underground mine pool and B-2 within mine waste saturated with AMD from the mine pool. Details regarding the site, bioremediation system, and geochemical monitoring are presented in our previous reports $[5,6,17,18]$.

\subsection{Biogeochemical Sulfur Cycling in the Tab-Simco PBS}

Figure 2 presents a simplified conceptual model of $S$ cycling in a typical PBS, such as the Tab-Simco PBS. In the open limestone channel, $\mathrm{S}$ sequestration occurs through precipitation of amorphous and crystalline $\mathrm{SO}_{4}{ }^{2-}$-bearing $\mathrm{nNP}$ such as schwertmannite $\left[\mathrm{Fe}_{8} \mathrm{O}_{8}(\mathrm{OH})_{6} \mathrm{SO}_{4}\right]$ and jarosite $\left[\mathrm{KFe}_{3}\left(\mathrm{SO}_{4}\right)_{2}(\mathrm{OH})_{6}\right]$ and by adsorption and incorporation into the $\mathrm{Fe}(\mathrm{III})$-rich nNP such as goethite $(\alpha-\mathrm{FeOOH})$ and lepidocrocite $(\gamma-\mathrm{FeOOH})$ [6] (Figure 2a). The presence in AMD of the detrital nanoand micro-scale particles (dNP), originated in the coal mine waste, promotes heterogeneous nucleation and growth of $\mathrm{SO}_{4}{ }^{2-}$-bearing $\mathrm{nNP}$ [6] and thus contributes to increased $\mathrm{SO}_{4}{ }^{2-}$ sequestration. Furthermore, alkalinity generated by limestone dissolution favors the precipitation of nNP. However, such precipitates would also form coatings on limestone, thus inhibiting alkalinity production [18]. Although the high capacity of $\mathrm{nNP}$ to sequester $\mathrm{SO}_{4}{ }^{2-}$ has been well documented, 
recent studies have shown that subsequent abiotic and biologically-mediated processes promote recrystallization and/or dissolution of $\mathrm{nNP}$, which results in $\mathrm{SO}_{4}{ }^{2-}$ remobilization [6,29].

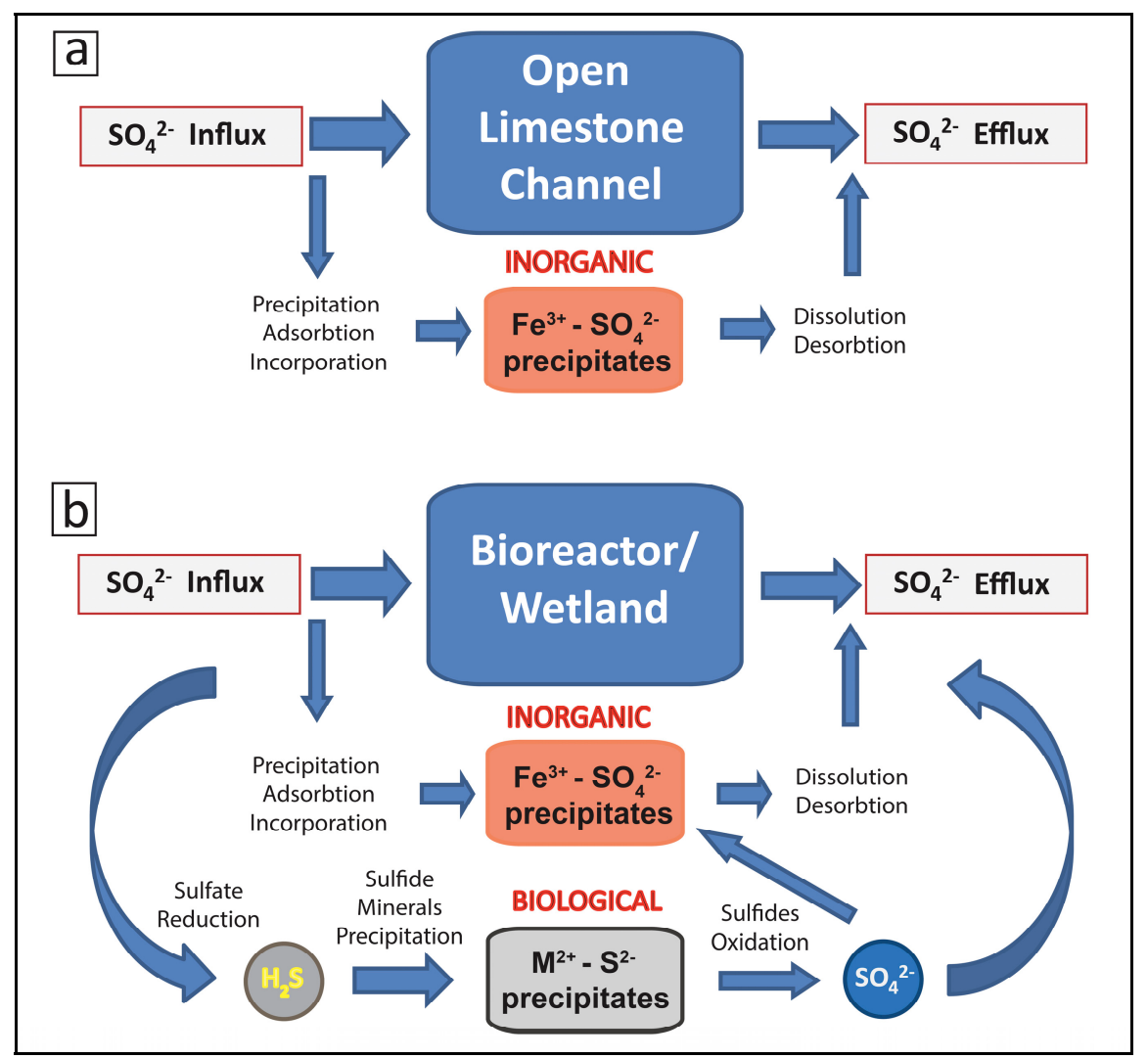

Figure 2. Simplified sulfur cycling and sequestration in a typical passive bioremediation system components: (a) the open limestone channel; and (b) the bioreactor and/or the wetland.

In the bioreactor and the wetland, $\mathrm{SO}_{4^{2-}}$ is sequestered as $\mathrm{SO}_{4^{2-}}{ }^{2}$-bearing $\mathrm{nNP}$ and by microbially-mediated reduction of $\mathrm{SO}_{4}{ }^{2-}$ to $\mathrm{H}_{2} \mathrm{~S}$ and precipitation of low-solubility metal-sulfide minerals. Optimal conditions for sulfate reducing microorganisms comprise anaerobic, alkaline settings with moderate salt and metal content as well as the availability of suitable electron donors, which may be either simple organic compounds or molecular hydrogen $\left(\mathrm{H}_{2}\right)$ [30-32]. Due to high spatial and temporal variability of environmental conditions in the bioreactor and wetland, zones of optimal BSR are therefore created, with their location and extent controlled by the distribution and nature of the microbial communities, availability of organic carbon, biochemical gradients, and overall local environmental conditions $[15,16]$. BSR-produced sulfide can then react with aqueous $\mathrm{Fe}(\mathrm{II})$ and/or with Fe(III)-bearing minerals and precipitate iron sulfides [5]. Transport of unreacted sulfide out of the bioremediation system commonly occurs in PBS (Figure 2b). Both dissolved sulfide and sulfide minerals are prone to oxidation either abiotically or by $\mathrm{S}$ oxidizing microorganisms, and this $\mathrm{S}$ fraction can be remobilized as $\mathrm{SO}_{4}{ }^{2-}$ back into solution. The residual $\mathrm{SO}_{4}{ }^{2-}$ that has not been reduced to $\mathrm{H}_{2} \mathrm{~S}$ or sequestered in $\mathrm{NNP}$ will be transported with the treated AMD out of the bioreactor cell. Finally, the continuous retention of the S-bearing phases as precipitates within the bioreactor cell results in mineral accumulations either as coating on reactive surfaces or as individual layers that can cause modification of the environmental conditions and a lowering of permeability in the PBS [6].

\subsection{Sulfur Isotope Systematics in the Tab-Simco PBS}

Sulfur isotope fractionation $\left({ }^{34} \mathrm{~S} /{ }^{2} \mathrm{~S}\right)$ has been used to differentiate biological from abiological $\mathrm{S}$ pathways, as tracers of sources, mixing processes and transformations of $S$ compounds in a variety 
of natural and engineered systems $[18,20]$. Both biological and abiotic processes can fractionate $\mathrm{S}$ isotopes, but microbial activity has been shown to produce larger fractionation in low-temperature, sedimentary environments [20,33].

In the Tab-Simco PBS, S biogeochemical cycle starts with the weathering of sulfide minerals in the coal mine waste. The sulfide minerals oxidation, both through abiogenic and biogenic pathways, produces dissolved $\mathrm{SO}_{4}{ }^{2-}$ with $\delta^{34} \mathrm{~S}$ reflecting the isotopic composition of sulfide minerals in the coal mine waste [18]. Within the Tab-Simco PBS, the dissolved $\mathrm{SO}_{4^{2-}}$ can be removed from the untreated and treated mine drainage through precipitation, co-precipitation, and sorption. Processes such as precipitation/dissolution of a wide range of $\mathrm{SO}_{4}{ }^{2-}$-rich minerals and adsorption/desorption of $\mathrm{SO}_{4}{ }^{2-}$ on surfaces, known to dominate the $S$ cycle in AMD-impacted environments [6], produce relatively small $S$ isotope fractionation between reactants and products $[24,25,33]$.

In the Tab-Simco bioreactor, biologically-mediated S cycling is expected to produce a diverse range of reactive S-species with different oxidation states (Figure $2 b$ ) and also generate distinct and often large $S$ isotope fractionations between various reactants and products $[15,16,20]$. For example, the microbially-mediated dissimilatory $\mathrm{SO}_{4}{ }^{2-}$ reduction to $\mathrm{H}_{2} \mathrm{~S}$ produces characteristic depleted $\delta^{34} \mathrm{~S}_{\mathrm{H} 2 \mathrm{~S}}$, with $\Delta^{34} \mathrm{~S}_{\mathrm{SO}} \mathrm{H}-\mathrm{H} 2 \mathrm{~S}$ up to $72 \%$ o $[15,16,20,23,33]$. BSR-produced $\mathrm{H}_{2} \mathrm{~S}$ can then participate in chemical and biological processes. $\mathrm{H}_{2} \mathrm{~S}$ is available to react with $\mathrm{Fe}^{2+}$ and other dissolved divalent metals and precipitate sulfide minerals, thus contributing to the long-term sequestration of AMD contaminants. Only minor $\mathrm{S}$ isotope fractionation occurs during direct precipitation of sulfides from dissolved $\mathrm{H}_{2} \mathrm{~S}$ [20]. Residual $\mathrm{H}_{2} \mathrm{~S}$ that does not react with metals to form sulfide minerals may be re-oxidized under anoxic and oxic conditions abiotically as well as by a range of microorganisms $[17,34]$. The multi-step oxidation process of $\mathrm{H}_{2} \mathrm{~S}$ back to $\mathrm{SO}_{4}{ }^{2-}$ releases eight electrons and may include the production of intermediate $S$ species, such as sulfite, thiosulfate, and elemental sulfur [33]. Fe(III)-nNP, abundantly present in the bioreactor, can mediate the heterolytic dissociation of $\mathrm{H}_{2} \mathrm{~S}$ and, in coupled redox reactions, the formation of elemental sulfur $\left(\mathrm{S}^{0}\right)$ with no isotopic fractionation during complete consumption [20]. $\mathrm{S}^{0}$, which is relatively stable under the low $\mathrm{pH}$ conditions typical of AMD, can be microbially disproportionated to $\mathrm{SO}_{4}{ }^{2-}$ and $\mathrm{H}_{2} \mathrm{~S}$ with subsequent chemical reactions between the formed $\mathrm{H}_{2} \mathrm{~S}$ and the $\mathrm{Fe}(\mathrm{III})-\mathrm{nNP}$, which can lead to precipitation of sulfide minerals. Compared to initial $\mathrm{S}^{0}$, the $\delta^{34} \mathrm{~S}$ values are depleted in ${ }^{34} \mathrm{~S}$ by up to $9 \%$ in $\mathrm{H}_{2} \mathrm{~S}$ and enriched in ${ }^{34} \mathrm{~S}$ by up to $35 \%$ in $\mathrm{SO}^{4^{2-}}$ [20]. Repeated cycles of $\mathrm{SO}_{4}{ }^{2-}$ reduction followed by subsequent reoxidation of $\mathrm{H}_{2} \mathrm{~S}$ back to $\mathrm{SO}_{4}{ }^{2-}$ mediated by the abundant $\mathrm{Fe}(\mathrm{III})$-nNP typical for AMD can contribute to a ${ }^{34} \mathrm{~S}$-depleted $\mathrm{S}$ reservoir and large $\varepsilon^{34} \mathrm{~S}$ so4-H2S kinetic isotope fractionation. Overall, recycling $S$ in its most reduced valence state back to more oxidized forms could play a key, yet unexplored role in the overall S cycling in AMD-impacted systems. Sulfur isotopes, along with relevant physical, geochemical, and microbial data, can potentially be used to differentiate among the multiple and complex $S$ sequestration and mobilization pathways in a PBS.

\subsection{Microbial Communities in the Tab-Simco PBS}

Microorganisms play key roles in the metal and nutrient cycles in AMD-impacted environments due to their ability to adapt to a remarkable range of extreme conditions. With AMD characterized by low $\mathrm{pH}$ and high $\mathrm{SO}_{4}{ }^{2-}$ and $\mathrm{Fe}$ concentrations, the major metabolites are the oxidation and reduction of $\mathrm{Fe}$ and $\mathrm{S}$ for energy, and $\mathrm{CO}_{2}$ as a carbon source [34-38].

A snapshot of the microbial community present at the Tab-Simco site in August 2008 was obtained through the generation of 16S rRNA gene clone libraries [17]. This analysis indicated that bacteria related to Fe-oxidizing Gallionella species dominated the monitoring well B-1 (Figure 3). Recent detection of Gallionella-like sequences in AMD environments suggests that acidophilic members of the genus are important players in the oxidation of sulfide minerals in the coal mine waste and the continuous generation of AMD [38]. 




Figure 3. Abundance of bacterial 16S rRNA gene sequences in water samples collected at four sampled sites at the Tab-Simco site (data from Burns et al. [17]).

As the AMD moved from the underground mine system to the bioreactor (Figure 1), the community remained dominated by Fe-oxidizing bacteria (Figure 3). However, the predominant $\mathrm{Fe}$ oxidizer shifted to one related to a Ferrovum, a genus that has also been detected in a wide range of AMD sites [39-43]. This community analysis also suggested limited biological $S$ cycling in the pretreated AMD drainage as only $2 \%$ of the analyzed sequences were related to a potential $\mathrm{S}$ oxidizing Thiomonas species and no sequences related to $\mathrm{S}$ or $\mathrm{SO}_{4}{ }^{2-}$ reducers were detected (Figure 3). As the treated mine drainage was released from the bioreactor, the community strongly shifted away from one dominated by Fe oxidizers to one supporting biological $\mathrm{S}$ cycling. Organisms related to species capable of $\mathrm{S}$ and $\mathrm{SO}_{4}{ }^{2-}$ reduction, including the anaerobic Desulfuromonas (S reducer), Desulfotomaculum, and Desulfobacteraceae (family) were detected in the Bioreactor Outlet sample (Figure 3). In conjunction with the presence of reduced S species in the bioreactor, sequences related to the S oxidizer Sulfuricurvum were detected in abundance. Some species of Sulfuricurvum have been shown to completely oxidize $\mathrm{S}^{0}$, sulfide, or sulfite to $\mathrm{SO}_{4}{ }^{2-}$ and thrive in high-sulfide, low oxygen microenvironments [44]. As the AMD from the bioreactor travelled through the oxidation pond/wetland, the community in the effluent shifted back to one that was similar to the Bioreactor Inlet, in that it was dominated by Fe oxidizing bacteria and chloroplast-like sequences. However, the predominant sequence type detected was more closely related to the Fe-oxidizing genus Sideroxydans. While some acidophilic Sideroxydans species have been isolated, others are limited to circumneutral $\mathrm{pH}$ [45]. Thus, the Fe oxidizer phylotype shifts are most likely linked to the $\mathrm{pH}$ of the sample sites. It should be noted that $\sim 4.5 \%$ of the sequences detected in the System Outlet sample were still related to the $\mathrm{S}$ oxidizer Sulfuricurvum species, thus suggesting the remaining presence of some reduced $\mathrm{S}$ species as an electron source.

\section{Materials and Methods}

\subsection{Sampling and Geochemical Analyses}

Field parameters were measured and water samples collected at the Tab-Simco site over a six-year period at the following sampling locations: (1) Main Seep, the largest AMD seep feeding the bioreactor; (2) Bioreactor Inlet, the point where the AMD collection ditch discharges into the bioreactor cell; (3) Bioreactor Outlet, the point where the treated AMD emerges from the bioreactor 
cell; and (4) System Outlet, the point where the treated water exits the PBS and enters the receiving stream [5] (Figure 1). Sample sites 1 and 2 are connected by a limestone-lined ditch that also serves as a collection ditch for a series of smaller AMD seeps. Additional samples were periodically collected from the two monitoring wells: B-1 and B-2. Field parameters, including $\mathrm{pH}$ and temperature were measured on unfiltered samples immediately following sample collection using a HI9829 Hanna ${ }^{\circledR}$ multi-sensor probe (Hanna Instruments, Woonsocket, RI, USA). The pH electrode Hanna HI769828-1 field probe (pH/ORP) was calibrated with Orion $\mathrm{pH} 1.68,4.01$, and 7.00 buffers and then checked against a $\mathrm{pH} 10$ buffer. Water samples selected for laboratory analyses were filtered through $0.45 \mu \mathrm{m}$ cellulose acetate filter papers (Millpore ${ }^{\circledR} \mathrm{HAW}$, , Billerica, MA, USA) and stored at 4 ${ }^{\circ} \mathrm{C}$ if not analyzed immediately after collection. The samples were subsequently analyzed for dissolved anions (i.e., $\mathrm{SO}_{4}{ }^{2-}$ ) by means of ion chromatography (Dionex ${ }^{\circledR}$ ICS 2000, LabX, Midland, ON, Canada) using an IonPac ${ }^{\circledR}$ AS18 anion-exchange column (ThermoFisher Scientific, Waltham, MA, USA), [5,18]. The standard deviation for standard and duplicate sample analyses was consistently $<5 \%$ for $\mathrm{SO}_{4}{ }^{2-}$ analysis. Standard deviation bars are not displayed on figures as the symbol size for individual data points are larger than the standard deviation of the measurement.

\subsection{Stable Isotope Measurements}

The sulfur isotopic composition of dissolved $\mathrm{SO}_{4}{ }^{2-}$ in untreated and treated mine drainages, pore water $\mathrm{SO}_{4}{ }^{2-}$ in AMD sediments, and sulfide minerals was measured in selected samples collected at Tab-Simco PBS. Dissolved $\mathrm{SO}_{4}{ }^{2-}$ was recovered from filtered, acidified, water samples $\left(50 \mathrm{~mL}\right.$ ) by addition of $0.2 \mathrm{M} \mathrm{BaCl}_{2}$ solution and precipitation of $\mathrm{BaSO}_{4}$. Recovered $\mathrm{BaSO}_{4}$ was dried, weighed, and retained for isotope analysis [24,25]. Sulfide minerals were handpicked from Murphysboro and Mount Rorah coal samples and analyzed directly as mineral powder. In August 2013, when the limestone-amended organic substrate layer in the bioreactor was replaced during system maintenance, we collected additional samples from the bioreactor cell, which included AMD sediments deposited on top of the organic substrate [6] and a composite of the organic substrate materials. Porewater $\mathrm{SO}_{4}{ }^{2-}$ measurements were obtained by first collecting duplicate samples of sediment segments immediately after the cores were sectioned in the laboratory. Subsequently, these segments were transferred to $50-\mathrm{mL}$ centrifuge tubes and centrifuged for $30 \mathrm{~min}$ at 8000 relative centrifugal force $(\mathrm{RCF})$ to isolate the porewater from the sediment solids. Sulfate levels in this supernatant were determined as described for dissolved $\mathrm{SO}_{4}{ }^{2-}$.

Additionally, samples of sulfide minerals were collected from the bioreactor organic substrate. These sulfide minerals were separated from the organic matrix, rinsed with DI water, dried in the oven at $50{ }^{\circ} \mathrm{C}$ and, finally, analyzed directly as mineral powder. For sulfur stable isotope measurements, aliquots of $\mathrm{BaSO}_{4}, \mathrm{FeS}_{2}$, or FeS were loaded into tin cups, mixed with $\mathrm{V}_{2} \mathrm{O}_{5}$, and then combusted on-line in an EA 1110 elemental analyzer at $1010^{\circ} \mathrm{C}$ and analyzed with a Finnigan MAT 252 mass spectrometer. The analytical precision $( \pm 1 \sigma)$ of $\delta^{34} S$ values was $< \pm 0.05 \%$ o of reference materials, whereas sample reproducibility was typically $\pm 0.2 \%$. All isotopic data are expressed in customary $\delta^{34} S$ in parts per thousand $(\%)$ relative to Vienna Cañon Diablo Troilite (V-CDT). The following international standards were used for calibration: IAEA-S1 $=-0.3 \%$, IAEA-S2 $=+21.6 \%$, IAEA-S3 $=-31.3 \%$, NBS- $127=+20.3 \%$. Sulfur isotope results are presented in Table S1.

\section{Results and Discussion}

\subsection{Coal Composition and Sulfur Compounds in Coal and Coal Mining Waste}

In coal, $\mathrm{S}$ takes on several forms including organic, elemental, and inorganic [46,47]. The inorganic $S$ forms include sulfide and sulfate minerals, with pyrite being the main component in most coals $[48,49]$. The organic $S$ may occur in aromatic or heterocyclic macromolecular $S$ structures, thiol moieties, or thioether units, among others [46]. When coal and coal mining waste are exposed to oxygen-rich water during weathering, both organic and inorganic S-bearing compounds are 
oxidized and/or dissolved causing release of $\mathrm{SO}_{4}{ }^{2-}$, the end oxidation product of S-bearing compounds, in order to subsequently migrate into ground and surface water.

Murphysboro and Mt. Rorah coal seams in the Illinois Basin have variable total S contents ranging from $\sim 2 \%$ in low-S coals to more than $7 \%$ in high-S coals [48]. Coal mining solid waste (coal refuse) can be even more enriched in $S$ with values up to $20 \%$ [49]. The ratio of organic to inorganic $S$ can be quite variable, though in many low-S coals, the two $S$ fractions contribute about equally to the total $\mathrm{S}$ content. Besides pyrite, $\mathrm{Zn}$ - and $\mathrm{Pb}$-sulfides have also been identified [48]. Additional inorganic constituents include sulfate minerals (i.e., gypsum, jarosite), elemental sulfur, as well as clay minerals and quartz [46,48]. The ubiquitous presence of $S$ in coal and coal mining waste assures a constant influx of $\mathrm{SO}_{4}{ }^{2-}$ in drainages associated with coal mining.

At Tab-Simco, the AMD overall chemistry reflects the composition of Murphysboro and Mt. Rorah coals; however, the component ratios are dissimilar (Figure 4). In coal, which contains high amounts of clay minerals and quartz, $\mathrm{Al}$ and $\mathrm{Si}$ predominate, whereas, in $\mathrm{AMD}, \mathrm{SO}^{2-}$ is the dominant dissolved species followed by $\mathrm{Fe}, \mathrm{Al}$ and $\mathrm{Si}$ [49]. Likewise, even though $\mathrm{S}$ represents only $\sim 17 \%$ of the inorganic molar fraction in Murphysboro coal samples, it makes up $\sim 70 \%$ of the total dissolved load in Tab-Simco AMD [18] (Figure 4). This discrepancy is due to weathering patterns of coal and coal mining waste as well as to specific methods employed to measure contaminant transport in AMD. In coal, weathering of pyrite and other S-bearing compounds generate coal mine drainages enriched in $\mathrm{SO}_{4}{ }^{2-}$ and metals such as $\mathrm{Al}, \mathrm{Fe}, \mathrm{Mn}, \mathrm{Zn}, \mathrm{Ni}$ and $\mathrm{Cr}$. However, $\mathrm{SO}_{4^{2-}}$ sequestration is typically low in the coal mine waste, since most of the $\mathrm{SO}_{4}{ }^{2-}$ bearing minerals (e.g., gypsum, jarosite and schwertmannite) are relatively unstable and prone to dissolution, which promotes $\mathrm{SO}_{4}{ }^{2-}$ partition into the AMD [49].

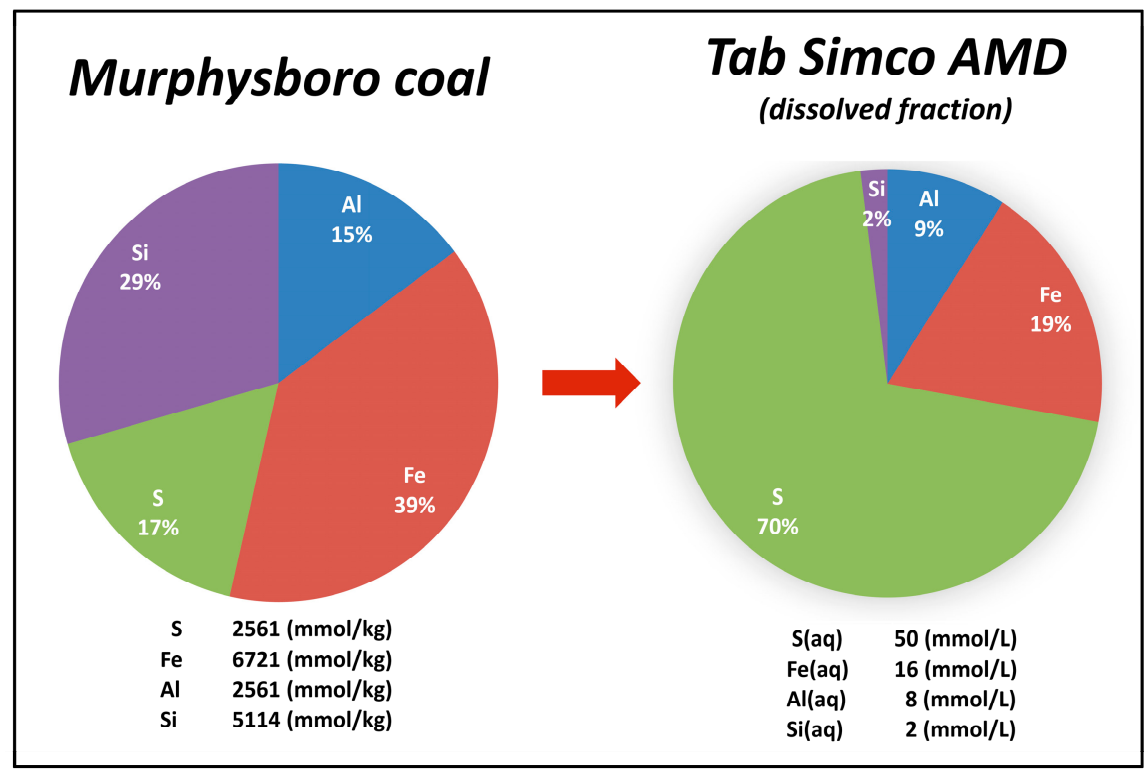

Figure 4. Percentage distribution and average concentrations of the main inorganic elements in Murphysboro coal and Tab-Simco acid mine drainage.

\subsection{AMD Drainage Characteristics}

\subsubsection{Examination of $\mathrm{pH}$ Variations}

The $\mathrm{pH}$ of the AMD influent measured during a six-year monitoring period at the Main Seep displayed values ranging between 2.3 and 3.2 and an average of 2.7 (Figure 5). The $\mathrm{pH}$ range was similar in well B-1 (2.7-3.5) and well B-2 (2.7-3.2) [5]. This result is surprising since during the same time period large variations of the hydroclimatic parameters were recorded including periods of extreme temperatures, droughts, and intense precipitation events. Because, at Tab-Simco, the AMD 
originates mostly in the underground mine workings, we can assume that steady-state conditions were maintained in the relatively thick cover of the reclaimed surface coal mine spoil throughout the duration of this study.

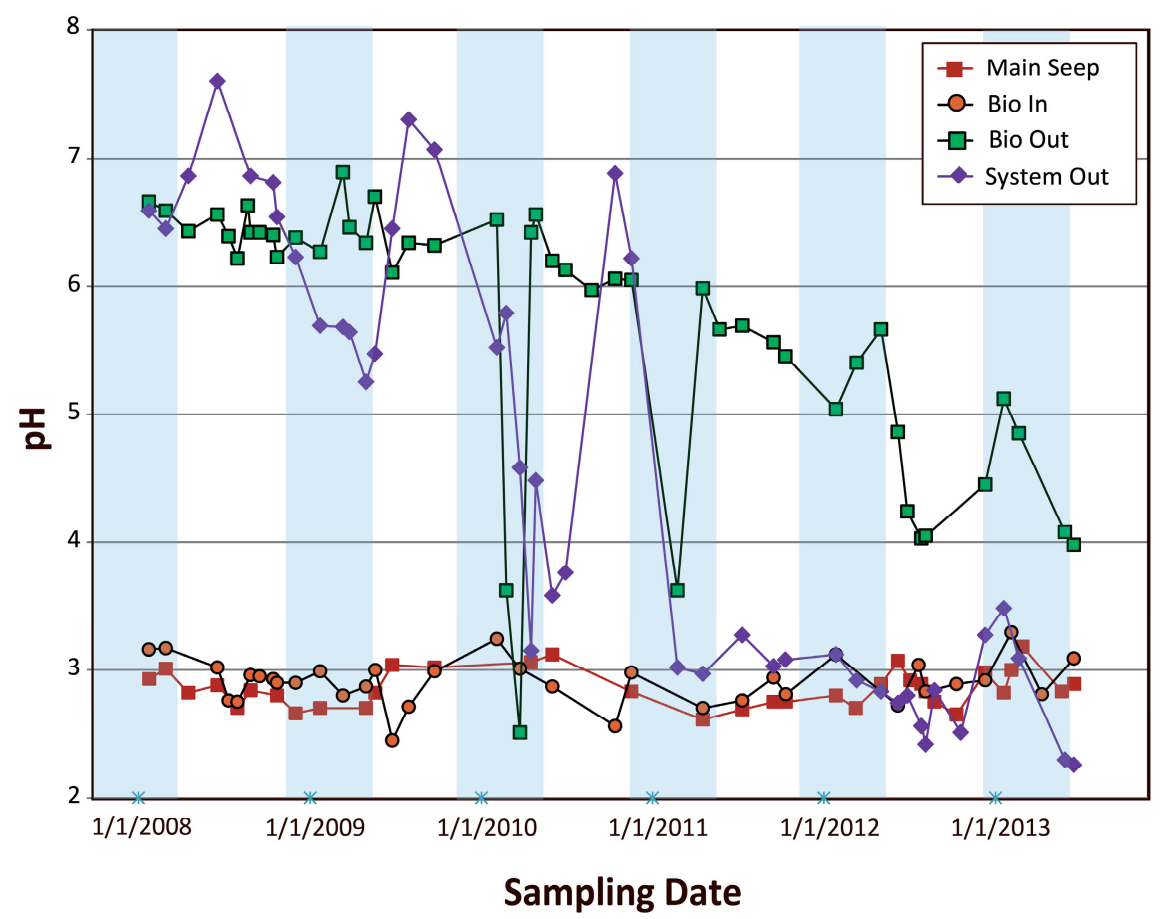

Figure 5. Temporal trends for $\mathrm{pH}$ measured in water samples collected at the Main Seep, Bioreactor Inlet (Bio In), Bioreactor Outlet (Bio Out), and the System Outlet (System Out).

Similar ranges of $\mathrm{pH}$ were recorded at both Bioreactor Inlet and Main Seep suggesting that the limestone channel had a limited capacity to buffer the influent AMD (Figure 5). An analogous finding was documented in our field experiments conducted to evaluate the effects of simple versus complex carbon sources on stimulating microbial sulfate reduction under low-pH conditions, where the limestone-only reactor, which lacked an organic substrate matrix, developed acidic conditions immediately after exposure to AMD [18]. In both cases, the passivation of the limestone by both $\mathrm{dNP}$, dominated by clay minerals, and $\mathrm{nNP}$, dominated by goethite, restricted limestone dissolution and alkalinity production [6,18].

The effluent $\mathrm{pH}$ measured at Bioreactor Outlet and System Outlet was initially higher than that of Main Seep, with values as high as 6.9 in the Bioreactor Outlet and 7.6 in the System Outlet (Figure 5). A pH $>6$ was measured year-round during the first two years of operation (2008-2010) in the Bioreactor Outlet and System Outlet, and the $\mathrm{pH}$ subsequently declined to $<6$ during winter and early spring. However, similar to trends observed in our field experiments [18], the advent of higher temperatures in the following summers led to higher $\mathrm{pH}$ values in the Bioreactor Outlet but not in the System Outlet (Figure 5).

Two main processes are responsible for creating alkalinity in the bioreactor and wetland, namely limestone dissolution and the presence of bacterial sulfate reduction. Low temperatures during winter months had a minimal influence on limestone dissolution; nevertheless, they strongly affected biological processes [18]. Thus, the decrease in $\mathrm{pH}$ in the Bioreactor Outlet and System Outlet during winter was most probably related to minimal bacterial activity and decreased BSR-generated bicarbonate alkalinity during the winter months. The $\mathrm{pH}$ temporal trends in Bioreactor Outlet also suggest that the microbial processes responsible for producing alkalinity within the bioreactor were less important after 2011. The overall gradual decrease of $\mathrm{pH}$ in Bioreactor Outlet and the fading and actually reversing winter-to-summer $\mathrm{pH}$ trend in Bioreactor 
Outlet through 2013 indicates that the bioreactor was able to buffer the AMD effectively only for the first four out of six years of treatment (Figure 5). In the wetland, lower organic matter availability to sustain BSR processes had a significant impact on its buffering capacity, which was maintained only for the first three years of Tab-Simco PBS operation.

\subsubsection{Examination of $\mathrm{SO}_{4}{ }^{2-}$ Concentration Variations}

The $\mathrm{SO}_{4}{ }^{2-}$ concentrations measured during the six-year period at the Main Seep varied between 2500 and $6200 \mathrm{mg} / \mathrm{L}$ with an average value of $4500 \mathrm{mg} / \mathrm{L}$ (Figure 6). Lower $\mathrm{SO}_{4}{ }^{2-}$ concentrations were measured in samples from the two monitoring wells B-1 and B-2, which ranged from 1000 to 3300 $\mathrm{mg} / \mathrm{L}$ with an average value of $2400 \mathrm{mg} / \mathrm{L}$ [5].

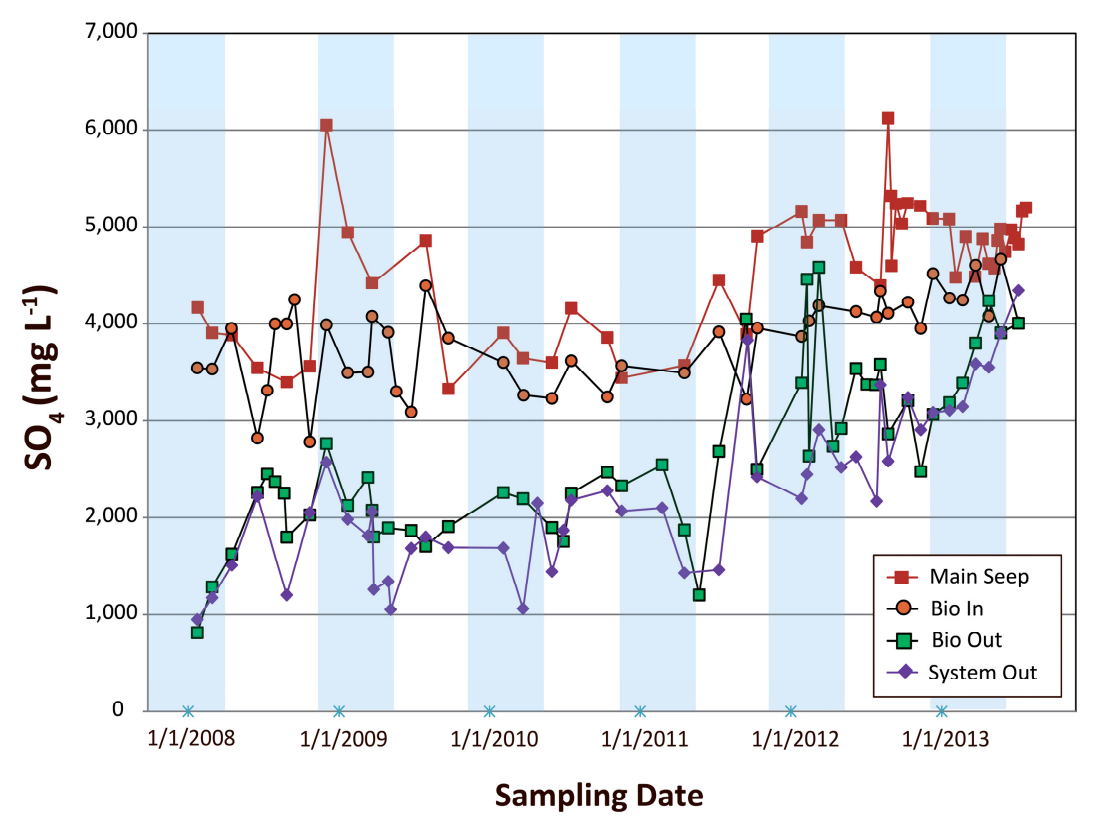

Figure 6. Temporal trends for the concentrations of dissolved sulfate $\left(\mathrm{SO}_{4}^{2-}\right)$ in water samples collected at the Main Seep, Bioreactor Inlet (Bio In), Bioreactor Outlet (Bio Out), and the System Outlet (System Out).

The large temporal variations in $\mathrm{SO}_{4}{ }^{2-}$ concentrations correlated with seasonal variations in hydroclimatic conditions at the site. Specifically, higher $\mathrm{SO}_{4}{ }^{2-}$ concentrations were recorded at the end of extended drought periods (e.g., 24 August 2012) and lower $\mathrm{SO}_{4}{ }^{2-}$ concentrations were measured after high-precipitation events (e.g., 24 March 2013). Previous investigations have also highlighted large seasonal variations of $\mathrm{SO}_{4}{ }^{2-}$ concentrations in AMD due to intense evaporation during drought periods and dilution by rainwater [37,50,51].

The $\mathrm{SO}_{4}{ }^{2-}$ concentration recorded in Bioreactor Inlet samples ranged between 3200 and 4500 $\mathrm{mg} / \mathrm{L}$ with an average of $3800 \mathrm{mg} / \mathrm{L}$ (Figure 6), suggesting that some dissolved $\mathrm{SO}_{4}{ }^{2-}$ may have precipitated out of the AMD along the limestone channel. Although precipitation of S-bearing nNP was documented between Main Seep and Bioreactor Inlet, the lower $\mathrm{SO}_{4}{ }^{2-}$ levels at the Bioreactor Inlet may have been also due to: (1) $\mathrm{SO}_{4^{2-}}$ contaminant transport as particulate (NP) and colloidal forms [6]; or (2) dilution with additional mine pool seepage with lower $\mathrm{SO}_{4}{ }^{2-}$ content [5].

Lower dissolved $\mathrm{SO}_{4}{ }^{2-}$ concentrations were systematically recorded at the Bioreactor Outlet and to an even greater extent at the System Outlet locations as compared to those measured at the Bioreactor Inlet (Figure 6). Overall, $\mathrm{SO}_{4}{ }^{2-}$ concentrations in the Bioreactor Outlet and System Outlet effluent steadily increased over time and, in the last year of PBS operation, approached the Bioreactor Inlet values. The overall contrasting trends of $\mathrm{pH}$ and $\mathrm{SO}_{4}{ }^{2-}$ in the Bioreactor Outlet and 
System Outlet suggest that the presence of bacterial sulfate reduction was critical in producing alkalinity and increasing $\mathrm{SO}_{4}{ }^{2-}$ sequestration in the PBS.

\subsubsection{Examination of Eh-pH Diagram}

Precipitate formation is the main $S$ sequestration mechanism in Tab-Simco PBS. To gain insight into such processes, we plotted the effluent datasets from Main Seep, Bioreactor Inlet, Bioreactor Outlet, and System Outlet into the Eh-pH diagram for Fe-S-K-O-H system at $25{ }^{\circ} \mathrm{C}$ (Figure 7). Previous reports have listed highly variable thermodynamic data for schwertmannite and ferrihydrite [52-54] so the Eh-pH stability fields are largely symptomatic.



Figure 7. Eh-pH diagram for Fe-S-K-O-H system at $25^{\circ} \mathrm{C}$. Stability fields for the mineral phases were plotted using available thermodynamic data from Bigham and Nordstrom [29]. Plotted data represent water samples collected at the Main Seep, Bioreactor Inlet (Bio In), Bioreactor Outlet (Bio Out), and System Outlet (System Out).

The examination of the diagram (Figure 7) reveals that the effluent data for the Main Seep and Bioreactor Inlet are distributed among the stability fields corresponding to $\mathrm{Fe}^{2+}(\mathrm{aq})$, schwertmannite, and goethite. The prevailing presence of Gallionella species, a Fe-oxidizing chemolithotrophic bacteria, in the well B-1 (Figure 3) suggest that active oxidation processes, sustained AMD production, and likely precipitation of Fe(III)-rich nNP were occurring in the coal mine waste [17].

When AMD from the coal mine waste, enriched in $\mathrm{SO}_{4}{ }^{2-}$ and $\mathrm{Fe}^{2+}$, reaches the surface at the Main Seep, $\mathrm{Fe}^{2+}(\mathrm{aq})$ is oxidized to $\mathrm{Fe}^{3+}$ both abiotically by molecular oxygen and microbially by Fe-oxidizing bacteria such as Ferrovum species, which were detected in the Tab-Simco open limestone channel (Figure 3). Hydrolysis of $\mathrm{Fe}^{3+}{ }_{(\mathrm{aq})}$ with subsequent precipitation of nNP such as goethite, schwertmannite, jarosite, or ferrihydrite has been documented by our field studies $[6,18]$. The particular nNP type depends on the Eh-pH conditions and the availability of key elements such as potassium and sulfur (Figure 7). These initially-precipitated nNP are metastable and in time tend to transform to well-crystalized goethite [6]. The hydrolysis and precipitation of Fe-rich nNP produce protons and thus are acid generating reactions [6].

Samples from the Bioreactor Outlet plot in the stability fields of pyrite, goethite, schwertmannite, and nano-crystalline $\mathrm{Fe}(\mathrm{OH})$, suggesting that there is heterogeneity in terms of bioreactor treatment performance. The Eh- $\mathrm{pH}$ values in the Bioreactor Outlet are not directly 
representative for the redox conditions inside the bioreactor because the partially-treated AMD discharge was unavoidably exposed to the atmosphere due to the design of the discharge pipe [5].

With this caveat, the data suggest that the bioreactor promoted the sequestration of $\mathrm{SO}_{4}{ }^{2-}$ both as sulfide and $\mathrm{SO}_{4}{ }^{2-}$-rich nNP. Microorganisms related to species capable of sulfur (e.g., anaerobic Desulfuromonas ) and sulfate (e.g., Desulfotomaculum, and Desulfobacteraceae ) reduction were detected in the Bioreactor Outlet (Figure 3), suggesting that active BSR processes occurred in the bioreactor cell [17]. Furthermore, the presence of S-bearing precipitates was confirmed when the bioreactor media was replaced in August 2013. The organic substrate contained micron-sized iron sulfides as well as $\mathrm{SO}^{2}{ }^{2-}$-rich $\mathrm{nNP}$ found primarily as coating the organic matter and limestone surfaces. Additionally, a sediment layer with an average thickness of $0.5 \mathrm{~m}$ was found on top of the organic substrate. This layer developed due to the accumulation of both transported and within-cell precipitated NP [6].

Samples from the System Outlet plot predominantly in the stability field of nNP, namely goethite, schwertmannite, and nano-crystalline $\mathrm{Fe}(\mathrm{OH})_{3}$ with some samples hosted in the $\mathrm{Fe}^{2+}(\mathrm{aq})$ stability field. This is in accordance with active $\mathrm{Fe}^{2+}{ }_{(\mathrm{aq})}$ oxidation processes occurring in the wetland mediated by either molecular oxygen and/or the Fe-oxidizing Betaproteobacteria Sideroxydans (Figure 3) with subsequent precipitation of $\mathrm{SO}_{4}{ }^{2-}$-rich nNP. Additional reduction of $\mathrm{Fe}^{3+}(\mathrm{aq})$ and/or $\mathrm{Fe}^{3+}-$ bearing $\mathrm{nNP}$ in the wetland by members of the Acidiphilium genus could have entered some $\mathrm{Fe}^{2+}$ (aq) in the System Outlet effluent.

\subsection{Sulfur Isotope Patterns in the Tab-Simco PBS}

\subsubsection{Sulfur Isotope Composition of Murphysboro and Mt. Rorah Coals}

The S-bearing phases in Murphysboro and Mt. Rorah coals exhibit $\delta^{34} S$ ranging from $-2.7 \%$ o to $+19.8 \%$ [ [48], which are within the range $\left(\delta^{34} \mathrm{~S}=-10.2 \%\right.$ o to $+26.8 \%$ o) reported for coals from the Illinois Basin [46-49,55,56]. The organic sulfur (S-or) and elemental sulfur (S-el) fractions in both for Murphysboro and Mt. Rorah coals were somewhat enriched in ${ }^{34} \mathrm{~S}\left(\delta^{34} \mathrm{~S}=+3.4 \%\right.$ o to $+19.8 \%$ ) whereas pyrite (S-py), water-soluble $\mathrm{SO}_{4}{ }^{2-}(\mathrm{S}-\mathrm{ws})$ and acid soluble $\mathrm{SO}_{4}{ }^{2-}$ (S-as) fractions were ${ }^{34}$-depleted $\left(\delta^{34} \mathrm{~S}=-2.7 \%\right.$ o to $+14.1 \%$ ) (Figure 8$)$. The variability in $\delta^{34} \mathrm{~S}$ for pyritic sulfur $\left(\delta^{34} \mathrm{~S}=-1.1 \%\right.$ o to $+12.7 \%$ ) was due to the presence of several generations of pyrite formed during the different stages of coalification as well as the impact of hydrothermal fluids that precipitated reduced sulfur in Illinois coals $[48,49]$. Detailed information about the sequential extraction method used to extract different $S$ fractions from coal samples and an in-depth discussion of the results were presented by Singh [48].

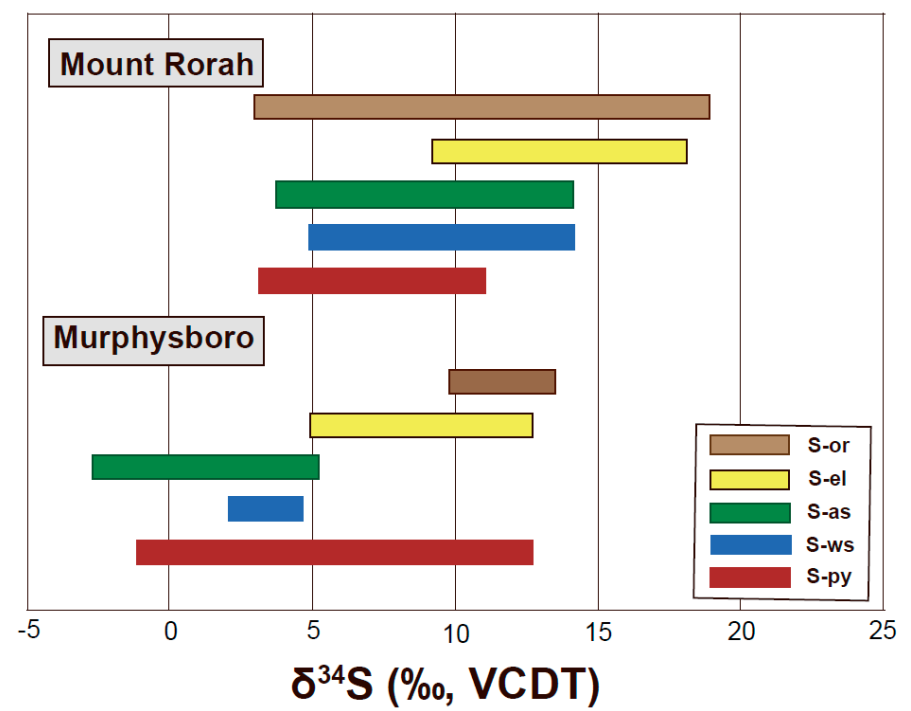

Figure 8. Range of sulfur isotopes values of sulfur fractions from Murphysboro and Mt. Rorah coal samples: organic sulfur (S-or), elemental sulfur (S-el), acid-soluble sulfur (S-as), water-soluble sulfur 
(S-ws) and pyritic sulfur (S-py). Data S-py are tabulated in Appendix A1 and previously published data for S-or, S-el, S-as, and S-ws are from Singh [48].

\subsubsection{Sulfur Isotope Composition of Dissolve Sulfate in AMD}

During the six-year monitoring period, AMD samples from Main Seep, well B-1, and well B-2 showed narrow $\delta^{34} \mathrm{~S}$ so4 ranges $\left(\delta^{34} \mathrm{~S}=+5.3 \%\right.$ o to $+7.6 \%$ ) (Figure 9a), despite the wide $\delta^{34} \mathrm{~S}$ ranges of S-bearing phases in Murphysboro and Mt. Rorah coals (Figure 8). A similar pattern was reported at an abandoned coal mine site in Indiana, where the weathering of coal containing S-bearing phases characterized by large $\delta^{34} S$ variations $\left(\delta^{34} \mathrm{~S}=-24.4 \%\right.$ o to $+9.9 \%$ ) produced an AMD with a $\delta^{34} \mathrm{~S}$ so4 narrow range $\left(\delta^{34} \mathrm{~S}=+8 \%\right.$ o to $+10 \%$ ) [50]. Most probably, the gradual weathering of the two main S-bearing phases in the coal and coal mine waste, namely the ${ }^{34}$ S-enriched organic-S and ${ }^{34} \mathrm{~S}$-depleted pyritic-S, resulted in a homogeneous $\delta^{34} \mathrm{~S}$ signature of dissolved $\mathrm{SO}_{4}{ }^{2-}$ in $\mathrm{AMD}$.

The narrow and overlapping $\delta^{34}$ Sso4 ranges of wells B-1 and B-2, Main Seep, and Bioreactor Inlet (Figure 9) suggest that, in the underground mine pool, coal mine waste, and open limestone channel, the $\mathrm{S}$ cycling was mostly dominated by processes that resulted in minor isotope fractionation such as abiogenic or biogenic sulfide oxidation in the coal mine waste [20,24], adsorption/desorption of $\mathrm{SO}_{4}{ }^{2-}$ onto available surfaces, and precipitation/dissolution of $\mathrm{SO}^{2-}{ }^{2-}$-rich nNP [6], which produced relatively small $S$ isotope fractionation between reactants and products $[24,25,56]$. In contrast, the wider $\delta^{34} S_{s 04}$ ranges of Bioreactor Outlet and System Outlet effluents, which also overlap and contained the most positive (Figure 9a) and variable isotopic values (Figure 10a), suggested that BSR occurred in these systems. The $\delta^{34} \mathrm{~S}$ so4 range was $+5.9 \%$ o to $+10.8 \%$ o for Bioreactor Outlet and $+5.9 \%$ o to $+10.4 \%$ o for System Outlet effluent samples.

The $\mathrm{S}$ cycle was further investigated in 2013 when the organic substrate of the bioreactor was replaced. At that time, we collected water samples from the bioreactor acid pond and Bioreactor Outlet and samples from the AMD sediments and the organic substrate layer [6]. Distinct $\delta^{34} S$ ranges were determined for the dissolved $\mathrm{SO}_{4}{ }^{2-}$ in the acidic water layer that overlies the organic substrate $\left(\delta^{34} \mathrm{~S}=+6.1 \%\right.$ o to $+6.4 \%$ ) , porewater $\mathrm{SO}_{4}{ }^{2-}$ in the upper Fe-rich sediments $\left(\delta^{34} \mathrm{~S}=+4.4 \%\right.$ o to $+5.9 \%$ o), porewater $\mathrm{SO}_{4}{ }^{2-}$ in the lower $\mathrm{Al}$-rich sediments $\left(\delta^{34} \mathrm{~S}=+3.7 \%\right.$ o to $+4.7 \%$ ), sulfide minerals embedded in the organic substrate $\left(\delta^{34} \mathrm{~S}=-2.3 \%\right.$ o to $+4.6 \%$ ), and the porewater $\mathrm{SO}_{4}{ }^{2-}$ in the organic substrate $\left(\delta^{34} \mathrm{~S}=+6.9 \%\right.$ o to $+7.8 \%$ o (Figure $\left.9 \mathrm{a}\right)$.

(a)

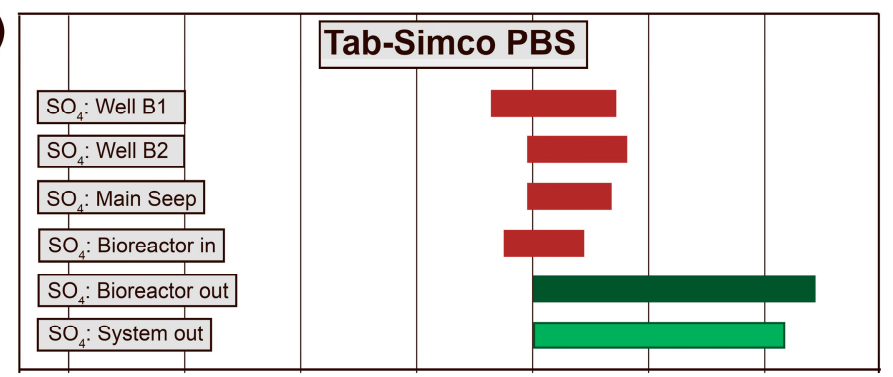

(b)

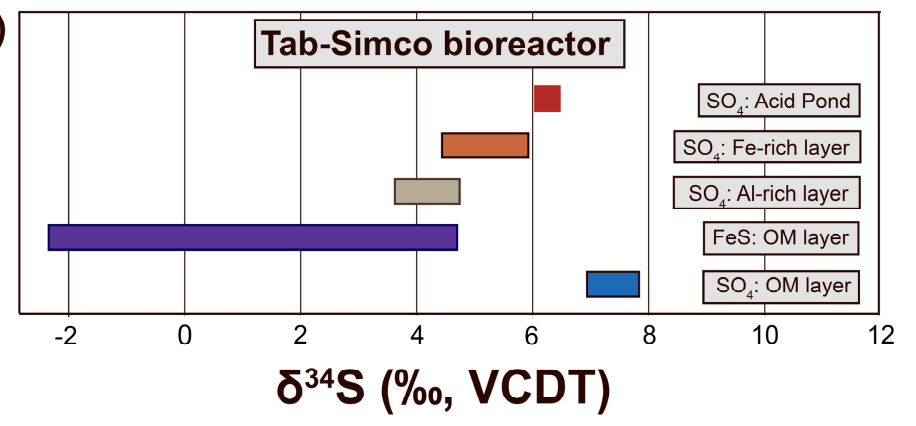


Figure 9. Ranges of sulfur isotopes values of (a) dissolved sulfate $\left(\mathrm{SO}_{4}{ }^{2-}\right)$ in water samples collected at different sampling points across the Tab-Simco PBS; and (b) dissolved and solid sulfur fractions from the Tab-Simco bioreactor collected in August 2013 when the bioreactor media was replaced.

Within the Tab-Simco PBS, the widest range of $\delta^{34} S\left(\delta^{34} \mathrm{~S}=-2.3 \%\right.$ o to $+10.8 \%$ ) was associated with the bioreactor (Figure 9). The observed $\delta^{34} S$ patterns can be best explained by an active, biologically-mediated $S$ cycle that involved both oxidizing and reducing pathways. The restricted presence of ${ }^{34} \mathrm{~S}$-depleted sulfide minerals in the organic substrate suggests that BSR processes were limited to this layer within the bioreactor. Within the organic substrate, BSR-produced $\mathrm{H}_{2} \mathrm{~S}$ reacted with $\mathrm{Fe}^{2+}$ to precipitate sulfides and left behind a ${ }^{34} \mathrm{SsO4}_{-}$-enriched pool (Figure $9 \mathrm{~b}$ ). Partial re-oxidation of ${ }^{34} \mathrm{~S}$-depleted $\mathrm{H}_{2} \mathrm{~S}$ back to $\mathrm{SO}_{4}{ }^{2-}$ also occurred in the bioreactor as representative chemolithoautotrophic, S oxidizing bacteria of genus Sulfuricuroum were found in the Bio Outlet (Figure 3). Similarly, when unreacted $\mathrm{H}_{2} \mathrm{~S}$ upwelled from the organic substrate, as it passed through the overlaying AMD sediment layer deposited on the top of the organic substrate [6], it was oxidized by $\mathrm{S}$ oxidizing microorganisms back to $\mathrm{SO}_{4}{ }^{2-}$. The ${ }^{34} \mathrm{~S}$-depleted porewater $\mathrm{SO}_{4}{ }^{2-}$ in the Fe- and $\mathrm{Al}$-rich layers (Figure $9 \mathrm{~b}$ ) were most probably the result of mixing between the ${ }^{34} \mathrm{~S}$-depleted porewater $\mathrm{SO}_{4}{ }^{2-}$ resulting from $\mathrm{H}_{2} \mathrm{~S}$ oxidation and the $\mathrm{SO}_{4}{ }^{2-}$ from the downward infiltration of acidic water that pool on top of the bioreactor. Overall, the magnitude of ${ }^{34} \mathrm{~S}$ enrichment of the effluent $\mathrm{SO}_{4}{ }^{2-}$ is an indication of the presence of bacterial sulfate reduction as the AMD was treated in the Tab-Simco bioreactor $[15,16]$.

\subsubsection{Sulfur Isotope Temporal Trends}

Temporal trends of sulfur isotopes were monitored both as $\delta^{34} S_{s 04}$ at the four monitoring points (Figure 10a) and as sulfur isotopic differences between the Main Seep and the Bioreactor Inlet, Bioreactor Outlet, and System Outlet, which are reported in capital delta notation $\Delta^{34}$ S (Figure 10b). The initial $\Delta^{34} S$ values were relatively large $\left(\Delta^{34} S_{\text {Bio Out-MS }} \geq+4 \%\right.$ ond $\Delta^{34} S_{\text {System Out-MS }} \geq+3.8 \%$ ), which gradually decreased to negative $\Delta^{34} S$ in the winter of 2013, in contrast to the small variations $\left(\triangle^{34} S_{\text {Bio In-MS }} \leq+1.3 \%\right.$ ) recorded at the Bioreactor Inlet over the same time period (Figures $10 \mathrm{~b}$ ). 



Figure 10. Temporal trends for (a) the sulfur isotope values of dissolved sulfate $\left(\delta^{34} \mathrm{SsO}_{\mathrm{s}}\right)$ in water samples collected from the Main Seep (MS), Bioreactor Inlet (Bio In), Bioreactor Outlet (Bio Out), and the System Outlet (System Out); and the (b) difference between the sulfur isotopic values of the Bio In, Bio Out, and System Out effluent dissolved sulfate and MS influent dissolved sulfate $\left(\Delta^{34} \mathrm{SsO}\right)$.

These trends are consistent with the $\mathrm{S}$ cycling being dominated by the inorganic precipitation processes in the limestone channel and the presence of bacterial sulfate reduction in the bioreactor and possibly in the wetland. Significantly, the $\Delta^{34} S_{\text {Bio Out-Ms }}$ trends (Figure 10b), which showed sharp decreases during low-temperature periods and the overall gradual decreases in $\Delta^{34} S_{\text {Bio Out-MS values, }}$ suggest that BSR processes were characterized by large temporal and spatial variabilities. The seasonal trends in $\mathrm{S}$ isotope are related to those of $\mathrm{pH}$ (decreasing) and $\mathrm{SO}_{4}{ }^{2-}$ (increasing) that can be explained by the temperature dependence of BSR processes $[18,37,57,58]$. The negative $\Delta^{34} S_{\text {Bio Out-MS }}$ recorded in winter of 2012 and 2013 are indicative of the addition of a ${ }^{34}$ Sso4-depleted pool resulted probably from re-oxidation of ${ }^{34} \mathrm{~S}$-depleted sulfide minerals [59] within the bioreactor. The presence of diverse $\mathrm{S}$ oxidizing bacteria communities in the Bioreactor Outlet (Figure3) suggests that sulfide re-oxidation was an important component of the $S$ cycle within the bioreactor (Figure 2). The steady build-up of $\mathrm{Fe}(\mathrm{III})$-nNP in the bioreactor could also favor the re-oxidation of $\mathrm{H}_{2} \mathrm{~S}$ and thus the decrease in bioreactor capacity to sequester the $\mathrm{SO}_{4}{ }^{2-}$ contaminant. The gradual accumulation of $\mathrm{Fe}(\mathrm{III})-\mathrm{nNP}$ precipitates in the bioreactor was probably substantial during the winter time when the low-temperature and low-pH conditions negatively affected the BSR activities but not the inorganic precipitation of $\mathrm{SO}_{4}{ }^{2-}$ bearing $\mathrm{nNP}[18,60]$. Significantly, the positive $\Delta^{34} S_{\mathrm{Bio}}$ Out-MS values recorded during the warm periods suggest that BSR rebounded every spring with the advent of higher temperatures. One of the most notable results of our investigation is that even in the summer of 
2013, before the bioreactor organic substrate was replaced, the $\Delta^{34} S_{\text {Bio Out-Ms }}$ rebounded from $-0.5 \%$ o

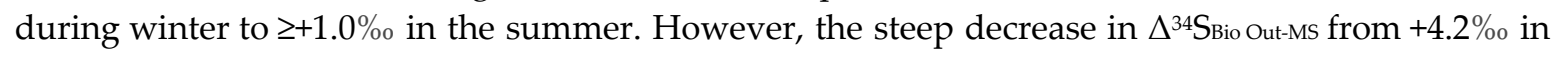
April 2008 to $+1.2 \%$ in April 2013 suggest that the contribution of BSR processes in sequestrating S within the bioreactor diminished over time. This trend was superimposed on the overall diminished $\mathrm{SO}_{4}{ }^{2-}$ sequestration in the Tab-Simco PBS.

In the case of the oxidation pond and aerobic wetland, the persistent lower $\Delta^{34}{ }^{3}$ system Out-Ms compared to $\triangle^{34} S_{\text {Bio Out-MS }}$ (Figure 10b) suggest that BSR processes, if present, had minimal influence on $\delta^{34} S_{s 04}$ values. On the contrary, these isotopic differences indicate that oxidation of dissolved and particulate sulfides originating in the bioreactor was an important part of the $\mathrm{S}$ cycling due to the continuous additions of a ${ }^{34} \mathrm{~S}$-depleted pool to dissolved $\mathrm{SO}_{4}{ }^{2-}$ already present in the wetland. Additional inorganic processes involving dissolved $\mathrm{SO}_{4}{ }^{2-}$, such as precipitation and dissolution of nNP were concurrently taking place; however, such processes cannot be quantified using $S$ isotopes because they have had a minimal impact on $S$ isotope variations.

\subsubsection{Using Sulfur Isotopes to Fingerprint BSR Processes}

The ability to identify the presence of bacterial sulfate reduction in a complex and dynamic $S$ cycle in a bioremediation system and quantify the formation of various reaction products is critical in monitoring the $\mathrm{SO}_{4}{ }^{2-}$ remediation efficiency in any PBS. This study revealed that during AMD treatment in the Tab-Simco bioreactor a significant fraction of $\mathrm{SO}_{4}{ }^{2-}$ was reduced through BSR, thus leading to a significant increase in the $\delta^{34} \mathrm{~S}$ of the residual $\mathrm{SO}_{4}{ }^{2-}$. This is a very promising result and suggests that $\mathrm{S}$ isotope monitoring can provide an additional tool for investigating $\mathrm{S}$ cycling in a bioremediation system by enabling the detection and monitoring BSR processes. Significantly, this approach integrates, in a single assessment, both the $\mathrm{SO}_{4}{ }^{2-}$ concentrations and the $\delta^{34} \mathrm{SsO4}$, which can be further used to estimate the contribution of BSR to $S$ sequestration in a PBS. The competition for $S$ sequestration among $\mathrm{SO}_{4}$-bearing $\mathrm{nNP}$ will have a minor effect on such an approach since sulfate mineral precipitation produces minor inorganic-induced shifts in $\delta^{34} S$.

Quantitative estimates of BSR involved in S sequestration can maximize the usefulness of $S$ isotopes approach and require knowledge of the isotope fractionation factors ( $\varepsilon^{34} \mathrm{~S}$ so4-H2s). Previous research has shown that the extent of $S$ isotope fractionation between sulfate and sulfide during BSR varies and depends on (i) the rate of metabolism by bacteria; (ii) the type and abundance of microbial sulfate reducers; (iii) the concentration and nature of the available electron donors; (iv) the thermal regime; and (v) the rate of sulfide removal.

Laboratory experiments that determined $\varepsilon^{34} \mathrm{~S}_{\mathrm{SO}} \mathrm{H}-\mathrm{H} 2 \mathrm{~S}$ produced by BSR have found that most of the values cluster around $\varepsilon^{34} \mathrm{~S}$ so4-H2S $\approx+25 \%$ o $\pm 10 \%$ [57]. Additional research on pure cultures found an inverse relationship between the cell specific rate of sulfate reduction (csSRR, fmol/cell-day) and the fractionation factor [57]. Large ranges of $\varepsilon^{34} \mathrm{~S}_{\mathrm{SO}} \mathrm{H}-\mathrm{H} 2 \mathrm{~S}$ were found to be a function of the available electron donor type and its rate of delivery. For example when a single organism isolated from marine coastal sediments (Desulfovibrio sp. strain DMSS-1) utilized different electron donors at BSR cell specific rates spanning two orders of magnitude, $\varepsilon^{34}$ Sso4-H2s varied from $-6 \%$ o to $-66 \%$ o $[61,62]$. Furthermore, by varying the delivery rate of a single electron donor (lactate) for a single organism (Desulfovibrio vulgaris Hildenborough), Leavitt et al. [63] found a 50-fold change in BSR rate with $\varepsilon^{34}$ Sso4-H2S varying from $-11 \%$ o to $-55 \%$. Temperature is also an important player in BSR since it controls both the $\mathrm{SO}_{4}{ }^{2-}$ reduction rates and the magnitude of $\varepsilon^{34} \mathrm{~S}_{\mathrm{SO}} \mathrm{H}-\mathrm{H} 2 \mathrm{~S}$. Using two strains of Archaeoglobus fulgidus, a hyperthermophilic sulfate reducer that was isolated from hot oil field production waters in the North Sea, Mitchell et al. [58] determined $\varepsilon^{34} \mathrm{SsO}_{4}-\mathrm{H}_{2} \mathrm{~S}$, which ranged between $-27 \%$ and $-0.5 \%$, with the largest fractionations found at intermediate temperatures and the smallest fractionations at the lowest and highest temperatures. In natural environments such as naturally occurring sediments and water bodies, most $\mathrm{S}$ fractionation factor values are clustered at $+45 \%$ o $\pm 10 \%$ o [20]. Generally, the laboratory and field experiments have stressed the intricate relationships between the measured $\varepsilon^{34} \mathrm{~S}$ sO4-H2S values and specific environmental conditions.

To estimate the contribution of BSR processes to $S$ sequestration in the Tab-Simco bioreactor, we performed a relatively simple isotope mass-balance calculation using the $\mathrm{SO}_{4}{ }^{2-}$ concentrations for the 
Bioreactor Inlet and Bioreactor Outlet sampling points and assuming that the $\Delta^{34} S_{\text {Bio Out-Bio In values }}$ are the sole result of BSR processes. Then, we ran our simplified model under two scenarios for which we selected two different $\varepsilon^{34}$ SsO4-H2S values, one representative for the laboratory experiments and the other for natural settings, namely $+25 \%$ ond $+45 \%$, respectively. These values were chosen because they span the temperature range of our field system. We are not proposing a new fractionation regime for BSR, but rather illustrating how the models respond to different assumptions about $\varepsilon^{34} \mathrm{~S}_{\mathrm{sO}} 4 \mathrm{H} 2 \mathrm{~s}$. Under the first scenario $\left(\varepsilon^{34} \mathrm{~S}_{\mathrm{SO}} \mathrm{-H} 2 \mathrm{~S}=+25 \%\right.$ o $)$, our calculations indicate that the contribution of BSR to S sequestration had decreased from 30\% on 27 August 2008, to 27\% on 18 July 2010, to $25 \%$ on 11 November 2011 and finally to 15\% on 24 May 2013. Under the second scenario $\left(\varepsilon^{34} \mathrm{~S}\right.$ sO4-H2S $=+45 \%$ ), the BSR contribution to S sequestration decreased from $21 \%$ on 27 August 2008, to 18\% on 18 July 2010, to 17\% on 11 July 2011 and finally to $<10 \%$ on 24 May 2013.

These estimates are broad, as many additional abiotic and microbial processes could have contributed to a complex $S$ cycling in the bioreactor. Further work is needed to specifically investigate the relationships between $\varepsilon^{34} \mathrm{~S}_{\mathrm{sO}}-\mathrm{H}_{2} \mathrm{~S}$ and environmental parameters in highly metalliferous AMD environments, including the types of BSR communities and electron donors, the cell specific rate of $\mathrm{SO}^{2-}$ reduction, and temperature, before they can be incorporated into robust quantitative models. Nonetheless, the result of the isotope mass-balance calculations underscores the importance of BSR processes as well as their decreasing contribution over time to $S$ sequestration in the Tab-Simco bioreactor.

\section{Conclusions}

This study highlights the key advantages of incorporating $S$ isotopes in monitoring $S$ cycling and sequestration in a PBS. By corroborating the sulfur isotope composition of dissolved sulfate and sulfide minerals with water chemistry, microbiology, and mineralogy data, we were able to differentiate between the two main mechanisms of $S$ sequestration, namely (1) the precipitation of $\mathrm{SO}_{4}{ }^{2-}$-bearing $\mathrm{nNP}$ and (2) the microbially-mediated sulfate reduction to sulfide and subsequent precipitation of sulfide minerals. Simultaneous monitoring of both $\mathrm{SO}_{4}{ }^{2-}$ concentrations and $\delta^{34} S_{s O 4}$ helped us (1) identify the areas within the PBS where BSR processes were actively important and had contributed to $S$ sequestration; (2) highlight the seasonality of BSR processes and therefore their dependence on temperature; and (3) estimate that the contribution of the BSR processes to $S$ sequestration in the Tab-Simco bioreactor decreased from up to $30 \%$ initially to less than $10 \%$ at the end of the six-year study period.

To increase the accuracy of the $S$ isotope approach and its use as indicator of BSR processes in PBS, additional investigations are needed into the complex $S$ redox pathways in the AMD-impacted environments, including the role and fate of intermediate $S$ species in redox processes and $S$ sequestration pathways. Further work is also needed on constraining the magnitude of isotope fractionations associated with specific microbial communities across different temperatures and with varying relevant electron donors. Additionally, incorporating oxygen isotopes of dissolved $\mathrm{SO}_{4}{ }^{2-}$ could help to better refine redox $\mathrm{S}$ pathways including fingerprinting disproportionation of intermediate $S$ species in the bioreactor since $S$ isotopes alone are insufficient to discriminate among these processes. Our results suggest that the further applications and development of this technique are warranted and can be employed in monitoring PBS treating drainages associated with coal and metal mining operations worldwide.

Supplementary Materials: The following are available online at www.mdpi.com/link, Table S1: Sulfur isotope composition of sulfur-bearing compounds from Tab-Simco passive bioremediation system.

Acknowledgments: We greatly acknowledge many SIUC researchers that helped us over the years with different aspects of this project, including Yosief T. Segid, Rajesh Singh, Andrew S. Burns, Charles W. Pugh, and Evan R. Walters. This work was supported by the Illinois Clean Coal Institute under Contract ICCI-07-1/ER11 and the Office of Surface Mining Reclamation and Enforcement (OSM) Applied Science Program Cooperative Agreement S11AC20018 AS. Additional support for stable isotope analysis was provided by the SIU Office of the Vice Chancellor for Research (OVCR). We want to acknowledge the landowner support, Treg Brown of 
Carbondale, for granting access to the field site. The Illinois Department of Natural Resources (IDNR), which operates the Tab-Simco PBS, also assisted our team for the duration of this study.

Author Contributions: L.L. conceived the research; L.L. and P.T.B. were directly involved in sample collection and analysis; K.S.B. performed microbial community analysis; M.L. participated in sample preparation and stable isotope analysis; and all authors contributed to data interpretation and writing the manuscript.

Conflicts of Interest: The authors declare no conflict of interest.

\section{References}

1. Cravotta, C.A. Dissolved metals and associated constituents in abandoned coal-mine discharges, Pennsylvania, USA. Part 1: Constituent concentrations and correlations. Appl. Geochem. 2008, 23, 166-202.

2. Palmer, M.A.; Bernhardt, E.S.; Schlesinger, W.H.; Eshleman, K.N.; Foufoula-Georgiou, E.; Hendryx, M.S.; Lemly, A.D.; Likens, G.E.; Loucks, O.L.; Powers, M.E.; et al. Mountain Mining Consequences. Science 2010, 327, 148-149.

3. Vengosh, A.; Lindberg, T.T.; Merola, B.R.; Ruhl, L.; Warner, N.R.; White, A.; Dwyer, G.S.; Di Giulio, R.T. Isotopic imprints of mountaintop mining contaminants. Environ. Sci. Technol. 2013, 47, 10041-10048.

4. Hudson-Edwards, K. Tackling mine wastes. Science 2016, 352, 288-290.

5. Behum, P.T.; Lefticariu, L.; Bender, K.S.; Segid, Y.T.; Burns, A.S.; Pugh, C.W. Remediation of coal-mine drainage by a sulfate-reducing bioreactor: A case study from the Illinois coal basin, USA. Appl. Geochem. 2011, 26, S162-S166.

6. Lefticariu, L.; Sutton, S.R.; Bender, K.S.; Lefticariu, M.; Pentrak, M.; Stucki, J.W. Impacts of detrital nano-and micro-scale particles (dNP) on contaminant dynamics in a coal mine AMD treatment system. Sci. Total Environ. 2017, 575, 941-955.

7. EPA. Health Effects from Exposure to High Levels of Sulfate in Drinking Water Study; EPA 815-R-99-001; U.S. Environmental Protection Agency, Office of Water: Washington, DC, USA, 1999; Volume 4607.

8. Geurts, J.J.; Sarneel, J.M.; Willers, B.J.; Roelofs, J.G.; Verhoeven, J.T.; Lamers, L.P. Interacting effects of sulphate pollution, sulphide toxicity and eutrophication on vegetation development in fens: A mesocosm experiment. Environ. Pollut. 2009, 157, 2072-2081.

9. Baldwin, D.S.; Mitchell, A. Impact of sulfate pollution on anaerobic biogeochemical cycles in a wetland sediment. Water Res. 2012, 46, 965-974.

10. Orem, W.; Fitz, H.C.; Krabbenhoft, D.; Tate, M.; Gilmour, C.; Shafer, M. Modeling sulfate transport and distribution and methylmercury production associated with Aquifer Storage and Recovery implementation in the Everglades Protection Area. Sustain. Water Qual. Ecol. 2014, 3, 33-46.

11. Willacker, J.J.; Eagles-Smith, C.A.; Ackerman, J.T. Mercury bioaccumulation in estuarine fishes: Novel insights from sulfur stable isotopes. Environ. Sci. Technol. 2017, 51, 2131-2139.

12. Johnson, D.B.; Hallberg, K.B. Acid mine drainage remediation options: A review. Sci. Total Environ. 2005, 338, 3-14.

13. Neculita, C.M.; Zagury, G.J.; Bussière, B. Passive treatment of acid mine drainage in bioreactors using sulfate-reducing bacteria. J. Environ. Qual. 2007, 36, 1-16.

14. Lindsay, M.B.; Blowes, D.W.; Condon, P.D.; Ptacek, C.J. Organic carbon amendments for passive in situ treatment of mine drainage: Field experiments. Appl. Geochem. 2011, 26, 1169-1183.

15. Branam, T. Optimization of Bioreactor Cell Design for Treating Low-Flow Acid Mine Drainage in the Midwest: Model Development and Demonstration; Final Report OSM Cooperative Agreement Number: S06PC12060; Indiana Geological Survey: Bloomington, IN, USA, 2009.

16. Reeder, M.D.; Reeder, T.D.; Olyphant, G.A. Assessment of Two Field-Scale Sulfate Reducing Bioreactors Using Sulfur Isotopes; National Meeting of the American Society of Mining and Reclamation: Pittsburgh, PA, USA; Bridging Reclamation, Science and the Community: Madrid, Spain, 2010.

17. Burns, A.S.; Pugh, C.W.; Segid, Y.T.; Behum, P.T.; Lefticariu, L.; Bender, K.S. Performance and microbial community dynamics of a sulfate-reducing bioreactor treating coal generated acid mine drainage. Biodegradation 2012, 23, 415-429.

18. Lefticariu, L.; Walters, E.R.; Pugh, C.W.; Bender, K.S. Sulfate reducing bioreactor dependence on organic substrates for remediation of coal-generated acid mine drainage: Field experiments. Appl. Geochem. 2015, 63, 70-82. 
19. Taylor, B.E.; Wheeler, M.C.; Nordstrom, D.K. Isotope composition of sulfate in acid mine drainage as a measure of bacterial oxidation. Nature 1984, 308, 538-541.

20. Canfield, D.E. Biogeochemistry of sulfur isotopes. Rev. Mineral. Geochem. 2001, 43, 607-636.

21. Fortin, D.; Rioux, J.P.; Roy, M. Geochemistry of iron and sulfur in the zone of microbial sulfate reduction in mine tailings. Water Air Soil Pollut. 2002, 2, 37-56.

22. Praharaj, T.; Fortin, D. Indicators of microbial sulfate reduction in acidic sulfide-rich mine tailings. Geomicrob. J. 2004, 21, 457-467.

23. Druhan, J.L.; Steefel, C.I.; Conrad, M.E.; DePaolo, D.J. A large column analog experiment of stable isotope variations during reactive transport: I. A comprehensive model of sulfur cycling and $\delta^{34} \mathrm{~S}$ fractionation. Geochim. Cosmochim. Acta 2014, 124, 366-393.

24. Lefticariu, L.; Pratt, L.M.; Ripley, E.M. Mineralogic and sulfur isotopic effects accompanying oxidation of pyrite in millimolar solutions of hydrogen peroxide at temperatures from 4 to $150{ }^{\circ} \mathrm{C}$. Geochim. Cosmochim. Acta 2006, 70, 4889-4905.

25. Lefticariu, L.; Schimmelmann, A.; Pratt, L.M.; Ripley, E.M. Oxygen isotope partitioning during oxidation of pyrite by $\mathrm{H}_{2} \mathrm{O}_{2}$ and its dependence on temperature. Geochim. Cosmochim. Acta 2007, 71, 5072-5088.

26. Smith, P.A. Characterization of an acid mine drainage site in Southern Illinois. In Proceedings of the 2002 National Meeting American Society of Mining and Reclamation, Lexington, KY, USA, 9-13 June 2002.

27. Korose, C.P.; Elrick, S.D. Coal geology of Illinois. In: 2010 Keystone Coal Industry Manual; Coal Age; Mining Media International: Jacksonville, FL, USA, 2010; pp. 456-467.

28. Lewis, L.L. Addressing acid mine drainage from complex conditions at the Tab-Simco mine (Jackson County, Illinois). In Proceedings of the 30th Annual National Association Abandoned Mine Land Programs Conference, Durango, CO, USA, 26-29 October 2008.

29. Bigham, J.M.; Nordstrom, D.K. Iron and aluminum hydroxysulfates from acid sulfate waters. Rev. Mineral. Geochem. 2000, 40, 351-403.

30. Barton, L.L.; Tomei, F.A. Characteristics and activities of sulfate-reducing bacteria. In Sulfate Reducing Bacteria; Barton, L.L., Ed.; Springer; New York, NY, USA, 1995; pp. 1-32.

31. Koschorreck, M. Microbial sulphate reduction at a low pH. FEMS Microbiol. Ecol. 2008, 64, 329-342.

32. Johnson, D.B. Geomicrobiology of extremely acidic subsurface environments. FEMS Microbiol. Ecol. 2011, $81,2-12$.

33. Balci, N.; Shanks, W.C., III; Mayer, B.; Mandernack, K.W. Oxygen and sulfur isotope systematics of sulfate produced by bacterial and abiotic oxidation of pyrite. Geochim. Cosmochim. Acta 2007, 71, 3796-3811.

34. Druschel, G.K.; Baker, B.J.; Gihring, T.M.; Banfield, J.F. Acid mine drainage biogeochemistry at Iron Mountain, California. Geochem. Trans. 2004, 5, 13-32.

35. Sánchez-Andrea, I.; Sanz, J.L.; Bijmans, M.F.; Stams, A.J. Sulfate reduction at low pH to remediate acid mine drainage. J. Hazard. Mater. 2014, 269, 98-109.

36. Senko, J.M.; Zhang, G.X.; McDonough, J.T.; Bruns, M.A.; Burgos, W.D. Metal reduction at low pH by a Desulfosporosinus species: Implications for the biological treatment of acidic mine drainage. Geomicrobiol. J. 2009, 26, 71-82.

37. Hazen, J.M.; Williams, M.W.; Stover, B.; Wireman, M. Characterization of acid mine drainage using a combination of hydrometric, chemical and isotopic analyses, Mary Murphy Mine, Colorado. Environ. Geochem. Health 2002, 24, 1-22.

38. Meier, J.; Piva, A.; Fortin, D. Enrichment of sulfate-reducing bacteria and resulting mineral formation in media mimicking pore water metal ion concentrations and $\mathrm{pH}$ conditions of acidic pit lakes. FEMS Microbiol. Ecol. 2012, 79, 69-84.

39. Fabisch, M.; Beulig, F.; Akob, D.M.; Küsel, K. Surprising abundance of Gallionella-related iron oxidizers in creek sediments at $\mathrm{pH} 4.4$ or at high heavy metal concentrations. Front. Microbiol. 2013, 4, 390.

40. Hallberg, K.B.; Coupland, K.; Kimura, S.; Johnson, D.B. Macroscopic streamer growths in acidic, metal-rich mine waters in North Wales consist of novel and remarkably simple bacterial communities. Appl. Environ. Microbiol. 2006, 72, 2022-2030.

41. Hua, Z.S.; Han, Y.J.; Chen, L.X.; Liu, J.; Hu, M.; Li, S.J.; Kuang, J.L.; Chain, P.S.; Huang, L.N.; Shu, W.S. Ecological roles of dominant and rare prokaryotes in acid mine drainage revealed by metagenomics and metatranscriptomics. ISME J. 2015, 9, 1280-1294.

42. Kay, C.M.; Haanela, A.; Johnson, D.B. Microorganisms in subterranean acidic waters within Europe's deepest metal mine. Res. Microbiol. 2014, 165, 705-712. 
43. Bruneel, O.; Personné, J.C.; Casiot, C.; Leblanc, M.; Elbaz-Poulichet, F.; Mahler, B.J.; Le Flèche, A.; Grimont, P.A. Mediation of arsenic oxidation by Thiomonas sp. in acid-mine drainage (Carnoulès, France). J. Appl. Microbiol. 2003, 95, 492-499.

44. Kodama, Y.; Watanabe, K. Sulfuricurvum kujiense gen. nov., sp nov., a facultatively anaerobic, chemolithoautotrophic, sulfur-oxidizing bacterium isolated from an underground crude-oil storage cavity. Int. J. Syst. Evol. Microbiol. 2004, 54, 2297-2300.

45. Mühling, M.; Poehlein, A.; Stuhr, A.; Voitel, M.; Daniel R.; Schlömann, M. Reconstruction of the metabolic potential of acidophilic Sideroxydans strains from the metagenome of a microaerophilic enrichment culture of acidophilic iron-oxidizing bacteria from a pilot plant for the treatment of acid mine drainage reveals metabolic versatility and adaptation to life at low pH. Front. Microbiol. 2016, 7, 2082.

46. Calkins, W.H. The chemical forms of sulfur in coal: A review. Fuel, 1994, 73, 475-484.

47. Chou, C.L. Sulfur in coals: A review of geochemistry and origins. Int. J. Coal Geol. 2012, 100, 1-13.

48. Singh, R. An Evaluation of the Sequential Extraction Method for Quantifying Sulfur Fractions in Coals from the Illinois Basin. Unpublished Master's. Thesis, Southern Illinois University, Carbondale, IL, USA, 2011.

49. Lefticariu, L. Integrated Study of Mercury and Other Trace Elements Distribution in Illinois Coal; Final Report; Illinois Clean Coal Institute: Carterville, IL, USA, 2009; 44p.

50. Hardisty, D.S.; Olyphant, G.A.; Bell, J.B.; Johnson, A.P.; Pratt, L.M. Acidophilic sulfur disproportionation. Geochim. Cosmochim. Acta 2013, 113, 136-151.

51. Demchak, J.; Skousen, J.; McDonald, L.M. Longevity of acid discharges from underground mines located above the regional water table. West Virginia Agricultural and Forestry Experiment Station, Morgantown, WV. Sci. Contrib. 2003, 2849, 656-668.

52. Majzlan, J.; Navrotsky, A.; Schwertmann, U. Thermodynamics of iron oxides: Part III. Enthalpies of formation and stability of ferrihydrite $\left(\sim \mathrm{Fe}(\mathrm{OH})_{3}\right)$, schwertmannite $\left(\sim \mathrm{FeO}(\mathrm{OH})_{3} / 4\left(\mathrm{SO}_{4}\right)_{1 / 8}\right)$, and $\varepsilon-\mathrm{Fe}_{2} \mathrm{O}_{3}$. Geochim. Cosmochim. Acta 2004, 68, 1049-1059.

53. Caraballo, M.A.; Rimstidt, J.D.; Macías, F.; Nieto, J.M.; Hochella, M.F. Metastability, nanocrystallinity and pseudo-solid solution effects on the understanding of schwertmannite solubility. Chem. Geol. 2013, 360, 22-31.

54. Bigham, J.M.; Schwertmann, U.; Traina, S.J.; Winland, R.L.; Wolf, M.; Schwertmannite and the chemical modeling of iron in acid sulfate waters. Geochim. Cosmochim. Acta 1996, 60, 2111-2121.

55. Price, F.T.; Shieh, Y.N. The distribution and isotopic composition of sulfur in coals from the Illinois Basin. Econ. Geol. 1979, 74, 1445-1461.

56. Elswick, E.R.; Hower, J.C.; Carmo, A.M.; Sun, T.; Mardon, S.M. Sulfur and carbon isotope geochemistry of coal and derived coal combustion by-products: An example from an Eastern Kentucky mine and power plant. Appl. Geochem. 2007, 22, 2065-2077.

57. Johnston, D.T.; Farquhar, J.; Canfield, D.E. Sulfur isotope insights into microbial sulfate reduction: When microbes meet models. Geochim. Cosmochim. Acta 2007, 71, 3929-3947.

58. Mitchell, K.; Heyer, A.; Canfield, D.E.; Hoek, J.; Habicht, K.S. Temperature effect on the sulfur isotope fractionation during sulfate reduction by two strains of the hyperthermophilic Archaeoglobus fulgidus. Environ. Microbiol. 2009, 11, 2998-3006.

59. Chirița, P.; Schlegel, M.L. Reaction of FeS with Fe(III)-bearing acidic solutions. Chem. Geol. 2012, 334, 131-138.

60. Wong, D.; Suflita, J.M.; McKinley, J.P.; Krumholz, L.R. Impact of clay minerals on sulfate reducing activity in aquifers. Microb. Ecol. 2004, 47, 80-86.

61. Sim, M.S.; Ono, S.; Donovan, K.; Templer, S.P.; Bosak, T. Effect of electron donors on the fractionation of sulfur isotopes by a marine Desulfovibrio sp. Geochim. Cosmochim. Acta 2011, 75, 4244-4259.

62. Sim, M.S.; Bosak, T.; Ono, S. Large sulfur isotope fractionation does not require disproportionation. Science 2011, 333, 74-77.

63. Leavitt, W.D.; Halevy, I.; Bradley, A.S.; Johnston, D.T. Influence of sulfate reduction rates on the Phanerozoic sulfur isotope record. Proc. Natl. Acad. Sci. USA 2013, 110, 11244-11249.

(C) 2017 by the authors; licensee Preprints, Basel, Switzerland. This article is an open access article distributed under the terms and conditions of the Creative Commons by Attribution (CC-BY) license (http://creativecommons.org/licenses/by/4.0/). 